B. Tuladhar / Our Nature (2003) 1: 26-29

\title{
Comparative Study of Fish Yields with Plant Protein Sources and Fish Meal
}

\author{
Babita Tuladhar* \\ Central Department of Zoology, Tribhuvan University, Kathmandu
}

\begin{abstract}
Two iso-nitrogenous and iso-caloric diets were formulated using Azolla, Soya bean and oilcakes as a sole protein source in diet B and fishmeal as sole protein in diet A. Six ponds were used as experimental ponds. The fishes of three ponds were supplied with Azolla diet B while the fishes of other three ponds were supplied with fish meal diet A. Growth of the fish in three ponds with plant protein sources was significant than in the fishes of other ponds with fish meal diet A. The yield of fish supplemented with Azolla, Soya beans and Oilcakes was higher than that of fish supplied with fishmeal diet.
\end{abstract}

\section{Introduction}

Nepal is an agricultural country where nearly $90 \%$ of the total population is involved in agriculture. The total productivity of fish in Nepal is 1.99 tonnes/hectare (FAO 1991, FAO1992) which comes to be $0.6 \%$ of the total agriculture .The total production and productivity of fish culture is very low in Nepal as compare to other countries due to the fact that fish culture is totally dependent upon natural food and very less or no supplementary food is provided to fishes by farmers. There is a great scope to enhance production of fish by supplementary feed. (Pantha 1993)

\section{Soya bean}

Soya bean meal is an excellent source of dietary protein for animals. Whole Soya bean contains about $40 \%$ of protein and $18 \%$ of Fat. The fat can be used by a feed formulator to add appreciable amounts of essential fatty acids to diet, and can also be used as a source of protein sparing energy (Jauncy and Ross1982)

*Correspondence: Birat Science Campus, Biratnagar

\section{Oilcakes}

Of the available plant proteins, Oilcakes are the most promising alternative to fishmeal diets. Oilcakes are the residues after the removal of the greater part of oil from oil seed. Most are tropical origin and are rich in protein (20\%-50\%) and include Soya bean, Cottonseed, Groundnut, Sun flower seed etc (Jauncy and Ross1982). Oilcakes contain $30.5 \%$ of crude protein and $14.7 \%$ of fat (Capper 1979).

\section{Azolla}

Azolla, a small aquatic macrophyte which is a common in most Asian rice fields, ponds and roadside ditches has considerable potential in fish culture, especially in rice fish system (Amalzan et al.1986). Fresh Azolla was preferred by a variety of both herbivorous and carnivorous fish. This aquatic macrophyte has a high content of protein; more over it has a high productivity for which it was selected for protein source for the experiment.

\section{Materials and Methods}

The experiment was performed at the Kathmandu Central Hatchery, (KCH) Balaju. The Total farm covers an area of 25 ha in which water surface covers 0.78 ha .6 ponds were 


\section{B. Tuladhar / Our Nature (2003) 1: 26-29}

selected for the experiment. The ponds were drained completely; weeds were cleaned and treated with hydrated lime at the rate of 500 $\mathrm{kg} / \mathrm{ha}$ before the experiment. The ponds having area of 0.05 ha were limed at the rate of $25 \mathrm{~kg}$ per pond. Then the ponds were left few days for complete drying and were filled with water up to $60 \mathrm{~cm}$. Water samples in the experimental ponds were analyzed before stocking the fingerlings. The different water quality parameters were recorded with the help of Hachkit (Hach Company, LoveLand, Colorado-USA)

Common carp (Cyprinus carpio), Silver Carp (Hypophthalmichthys molitrix), Rohu (Labeo rohita) and Mrigal (Cirrhinus mrigala) were selected for the experiment. An average initial weight of these fish were $30.0 \mathrm{gm}, 5.1 \mathrm{gm}, 8.1 \mathrm{gm}$ and $16.29 \mathrm{gm}$ respectively. The stocking rate of fish was 6000 fingerlings per hectare. The total numbers of fish used were 1650 out of which the number of Common Carp, Silver Carp, Rohu and Mrigal were 824,330,248 and 248 corresponding with 50, 20, 15 and 15 stocking percentage respectively. Two types of diets were selected; Azolla, Soya bean and Oilcakes in sole protein source as diet B and imported but locally available fishmeal as diet A.

Fingerlings were fed at the rate of $5 \%$ of body weight per day avoiding the feed required for silver carp. Total feed required per day was calculated according to the total body weights of the common carp, Rohu and Mrigal. Thus after stocking 281 gm day $^{-1}$ of diet A and 260 gm day ${ }^{-1}$ of diet $\mathrm{B}$ were given to the respective ponds. After 21 days growth check up was done and calculated the total growth of each variety of fish.

To supply the remaining nutrient requirement of the fish, ponds were manure once a week to produce natural food. $25 \mathrm{~kg} /$ week and $18.5 \mathrm{~kg} /$ week of manure were supplied in ponds of 0.05 ha and 0.0375 ha respectively.

Physico-chemical parameters (temperature, dissolved oxygen, $\mathrm{pH}$, alkalinity, free $\mathrm{CO}_{2}$ and total hardness) of water were analyzed by using standard methods of APHA (1989).

\section{Results and Discussion}

Depth of pond has an important role in the production of a pond. A pond having a depth of $2 \mathrm{~m}$ was considered congenial from the viewpoint of biological productivity of a pond. In the present experiment, although the average depth of the ponds was $0.8 \mathrm{~m}$, temperature recorded was $21.9^{\circ} \mathrm{C}$ to $23.9^{\circ} \mathrm{C}$ in all ponds. Dissolved oxygen before stocking ranged in between $5.6 \mathrm{mg} / \mathrm{l}$ to $10.1 \mathrm{mg} / \mathrm{l}$. $\mathrm{pH}$ ranges was found in between 6.7 to 8.1. Alkalinity ranged from 153 to $190 \mathrm{mg} / \mathrm{l}$ at stocking and 170 to $195 \mathrm{mg} / \mathrm{l}$ at harvesting period. $\mathrm{CO}_{2}$ concentration range in between 1.5 to $2.3 \mathrm{mg} / \mathrm{l}$. Total hardness ranged in between 149 to 209mg/l.

During this experiment diet A and diets B were observed to be equally accepted by fishes. The colour, texture and the smell of the diet throughout the experiment period appeared to have no effects on the voracious feeding nature of the fish.

Within the experimental period growth per day were found higher on fishes having diet B. Growth rate of common carp and silver carps were high in diet B as compare to diet A whereas the growth per day is similar in Rohu and Mrigal in both the diets (Diet A and diet B).

In this experiment average yield was $25.8 \mathrm{~kg}$ within 42 days. The total yields in all the ponds are given in Table.1 and 2. It was also observed that yield of fish was higher with diet $B$ than with diet A. The yield in 8 months period was $2568.10 \mathrm{~kg}$ in Diet A and 3839.90kg in diet B. So yield percentage increased in 8 months was $49.52 \%$ higher in diet B than diet A. Mean fish weight and mean total length of the fish fed with diet B was higher than diet A in common carp and silver carp. The growth performance of Rohu and Mrigal were similar in both the diets. 
Weight increment of common carp showed that in the $1^{\text {st }}$ year, it attained 300gms (Alikunhi 1966), $50 \mathrm{~cm}$ long Silver carp in $2^{\text {nd }}$ year gain 1,803gm weight (Chang et al.1983) while Rohu at the end of $2^{\text {nd }}$ year measured $1.75 \mathrm{~kg}$ (Khan and Jhingran 1975) and Mrigal in the $1^{\text {st }}$ year attained 245.7gm(Khan and Jhingran 1979). In the present experiment within 42 days of experimental periods common carp weighs 213.5gm (diet B) and 174.8gm (diet A). Silver carp attained average weight of 151.3gm with diet B and 85.7gm with diet A. Similarly Rohu measured $75.7 \mathrm{gm}$ with diet $\mathrm{B}$ and 52.8gm with diet A and Mrigal of 46.33gm with diet B and 49.6gm with diet A.

The temperature recorded through out the experimental period ranged from $21.9^{\circ} \mathrm{C}$ to $23.9^{\circ} \mathrm{C}$, which is an optimal temperature for carp culture. Dissolved Oxygen is one the most important factor affecting growth and causing mortality. Oxygen requirement of Common carp, Silver carp, Rohu and Mrigal are 0.2 to $0.8 \mathrm{mg} / \mathrm{l}, \quad 0.3$ to $1.1 \mathrm{mg} / \mathrm{l}$ and $0.7 \mathrm{mg} / \mathrm{l}$ respectively (Boyd 1988). Dissolved oxygen recorded in this experiment was 5.1 to $10.5 \mathrm{mg} / \mathrm{l}$. The optimum $\mathrm{pH}$ recorded value of fish ranged 6.5 to 9 (Woynarovich 1981). The optimum $\mathrm{pH}$ recorded was 6.7 to 8.1 in all ponds. Total alkalinity was $100 \mathrm{mg} / \mathrm{l}$, which is an ideal for fish growth. Total hardness ranged from $82 \mathrm{mg} / \mathrm{l}$ to $209 \mathrm{mg} / \mathrm{l}$ through out the experimental period. In the experiment $89.01 \mathrm{~kg}$ of diet was fed within 42 days, which helped to produce $62 \mathrm{~kg}$ fish. For the production of $1 \mathrm{~kg}$ of fish total diet required was $143 \mathrm{~kg}$. By feeding $66.24 \mathrm{~kg}$ of diet B, about $92.4 \mathrm{~kg}$ of fish was produced within 42 days. Thus to produce $1 \mathrm{~kg}$ of fish, total feed required was $0.716 \mathrm{~kg}$.

Table 1. Yield as comparison to both the diets.

\begin{tabular}{|l|c|c|c|c|c|c|}
\hline \multirow{2}{*}{ Fish Species } & \multicolumn{3}{|c|}{ Diet A } & \multicolumn{3}{c|}{ Diet B } \\
\cline { 2 - 7 } & $\begin{array}{c}\text { Stocking } \\
\text { Wt. (Kg) }\end{array}$ & $\begin{array}{c}\text { Harvesting } \\
\text { Wt . (Kg) }\end{array}$ & Yield (Kg) & $\begin{array}{c}\text { Stocking } \\
\text { Wt. (Kg) }\end{array}$ & $\begin{array}{c}\text { Harvesting } \\
\text { Wt. (Kg) }\end{array}$ & Yield (Kg) \\
\hline 1. Common Carp & 13.94 & 63.08 & 49.14 & 12.53 & 80.5 & 67.93 \\
\hline 2. Silver Carp & 0.729 & 7.78 & 7.051 & 0.97 & 19.05 & 18.08 \\
\hline 3. Rohu & 0.944 & 5.22 & 4.27 & 1.05 & 5.68 & 4.63 \\
\hline 4. Mrigal & 2.05 & 3.65 & 1.60 & 2.053 & 3.83 & 1.77 \\
\hline \multicolumn{1}{|c|}{ Total } & 17.663 & 79.73 & 62.06 & 16.60 & 109.06 & 92.41 \\
\hline \multicolumn{1}{|c|}{ Yield/Day } & & 1.47 & & & 2.2 \\
\hline
\end{tabular}

Table 2. Projected yield within eight months/hectare.

\begin{tabular}{|l|c|c|c|c|c|c|c|}
\hline \multirow{2}{*}{ Fish Species } & \multicolumn{7}{|c|}{ Diet A } \\
\cline { 2 - 8 } & $\begin{array}{c}\text { Initial } \\
\text { Wt.. } \\
\text { (Kg.) }\end{array}$ & $\begin{array}{c}\text { Final } \\
\text { Wt. } \\
\text { (Kg.) }\end{array}$ & $\begin{array}{c}\text { Total } \\
\text { Yield } \\
\text { (Kg.) } \\
\mathbf{4 2} \text { days }\end{array}$ & $\begin{array}{c}\text { Yield } \\
\text { Kg/day }\end{array}$ & $\begin{array}{c}\text { Yield } \\
\text { Kg./8 } \\
\text { month per } \\
\text { 0.137 ha. }\end{array}$ & $\begin{array}{c}\text { Yield } \\
\text { Kg./8 } \\
\text { month per } \\
\text { ha. }\end{array}$ & $\begin{array}{c}\text { Fish } \\
\text { Species } \\
\text { Yield \% }\end{array}$ \\
\hline 1. Common carp & 13.94 & 63.80 & 49.1 & 1.16 & 278.4 & 2032.1 & 79.1 \\
\hline 2. Silver carp & 0.729 & 7.78 & 7.051 & 0.167 & 40.08 & 292.5 & 11.4 \\
\hline 3. Rohu & 0.944 & 5.22 & 4.27 & 0.101 & 24.24 & 176.9 & 6.9 \\
\hline 4. Mrigal & 2.05 & 3.65 & 1.60 & 0.038 & 9.12 & 66.56 & 2.6 \\
\hline \multicolumn{1}{|c|}{ Total } & 17.66 & 79.73 & 62.02 & 1.46 & 351.84 & 2568.07 & 100 \\
\hline
\end{tabular}


B. Tuladhar / Our Nature (2003) 1: 26-29

\begin{tabular}{|l|c|c|c|c|c|c|c|}
\hline \multirow{2}{*}{ Fish Species } & \multicolumn{7}{|c|}{ Diet B } \\
\cline { 2 - 8 } & $\begin{array}{c}\text { Initial } \\
\text { Wt.. } \\
\text { (Kg.) }\end{array}$ & $\begin{array}{c}\text { Final } \\
\text { Wt. } \\
\text { (Kg.) }\end{array}$ & $\begin{array}{c}\text { Total } \\
\text { Yield } \\
\text { (Kg.) } \\
\mathbf{4 2} \text { days }\end{array}$ & $\begin{array}{c}\text { Yield } \\
\text { Kg/day }\end{array}$ & $\begin{array}{c}\text { Yield } \\
\text { Kg./8 } \\
\text { month } \\
\text { per } \\
\mathbf{0 . 1 3 7} \text { ha. }\end{array}$ & $\begin{array}{c}\text { Yield } \\
\text { Kg./8 } \\
\text { month } \\
\text { per ha. }\end{array}$ & $\begin{array}{c}\text { Fish } \\
\text { Species } \\
\text { Yield \% }\end{array}$ \\
\hline 1. Common carp & 12.53 & 80.5 & 67.97 & 1.61 & 386.4 & 2820.4 & 73.50 \\
\hline 2. Silver carp & 0.97 & 19.05 & 18.08 & 0.43 & 103.2 & 753.3 & 19.60 \\
\hline 3. Rohu & 1.05 & 5.68 & 4.63 & 0.11 & 26.45 & 192.7 & 5.0 \\
\hline 4. Mrigal & 2.053 & 3.83 & 1.77 & 0.042 & 10.08 & 73.57 & 1.90 \\
\hline \multicolumn{1}{|c|}{ Total } & 16.60 & 109.06 & 92.45 & 2.192 & 526.13 & 3839.97 & 100 \\
\hline
\end{tabular}

\section{Acknowledgements}

The author wishes to extend her profound gratitude to Mr. Madhab Bahadur Pantha, Chief, Fisheries Development Division, Department of Agriculture Development, Harihar Bhawan, Pulchowk, for his guidance, regular supervision and constant encouragement. The author is also indebted to Prof. Dr. Jeevan Shrestha, Central Department of Zoology, Tribhuwan University, Kirtipur, for her guidance.

The author express deep sense of gratitude to Dr. P. N. Mishra, Chairman, Central Department of Zoology, Tribhuvan University, Kirtipur for providing necessary laboratory facilities and opportunity to conduct the present work. I am grateful to Dr. Bharat Raj Subba, Head of the Department of Zoology, Post Graduate campus, Biratnagar for his suggestions and encouragements.

\section{References}

Alikunhi, K .H. 1966. Synopsis of biological data on Common carp (Cyprinus carpio) (Linn. 1758) (Asia \& Far East), FAO, Fish Synop.pp. 73.

Amalzan, G. J. R., S. V. Pullin, A. F. Angeles, T. .A. Manalo, R. A. Agbayani \& M. T. B. Trono 1986. Azolla pinnata as a dietary component for Nile Tilapia (Oreochromis niloticus). The first Asian Fisheries Forum. Asian Fisheries Soc. Manila, Phillipines. pp. 523-528

APHA 1989. Standard methods for examination of water and wastewater treatment. Amer. Publ. 24th Asso. Washington D. C.
Boyd, C. E. 1988. Water Quality Management for pond fish culture, Auburn University, Albama, U.S.A.,

Capper, B. S. 1979. Animal feed formulation \& manufacture in Nepal with particular reference to Fish \& Duck feed production .

Chang, W.Y., B. J. S. Diana and W. Chuapochatz 1983. Workshop report to agency for international development Strengthening of South - East Asian Agriculture Institutions ( Grant No. Dan 5543-GSS-2103-00 ) pp.30

FAO 1991. Fish for food \& development, Food \& Agriculture Organization of the United Nations, Rome pp.12.

FAO 1992. Nutrition the Global Challenge.International Conference on Nutrition. 5-11 Dec, 1992, Rome, pp.30

Khan, M. H and V. G. Jhingran 1975. Synopsis of biological data on labeo rohita (Hamilton 1822) FAO. Fish. Synop.II.pp.100.

Khan, M. H and V. G. Jhingran.1979.Synopsis of the biological data on Cirrhinus mrigal (Hamilton 1822) FAO, Fish, Synop.pp.120.

Jauncy, K and B. Ross 1982. A guide to Tilapia feeds \& feeding.Institute of Aqua. Uni. of Stirling, Scotland.

Pantha, M. B. 1993. Aquafeeds and feeding strategies in Nepal. In Proceedings of the FAO/AADCP Regional Expert Consultation on Farm - made aquafeeds, 14-18 Dec. 1992, Bangkok, Thailand, pp.434.

Woynarovich, E. 1981. Elementery guide to fish culture in Nepal. 